\title{
津波氾濫流による流体力への動圧の寄与と漂流物の衝突力の確率分布

\author{
Contribution of Dynamic Pressure to Fluid Force and Probability Distribution of \\ Collision Force of Floating Bodies due to Tsunami Inundated Flow
}

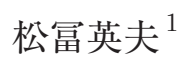

\section{Hideo MATSUTOMI}

\begin{abstract}
Contribution of dynamic pressure to fluid force on a vertical wall of buildings and so on due to tsunami inundated flow is examined through reviewing previous works on the fluid force, including those due to similar phenomena such as a breaking of wind waves. It is concluded that the contribution of dynamic pressure to the fluid force is not negligible and its degree depends on generation method, Froude number and degree of unsteadiness of the tsunami inundated flow in hydraulic experiments. A method for estimating probability distribution of collision force of floating bodies due to the tsunami inundated flow is also presented through examination of collision velocity, collision probability, duration of collision force and duration of rising time from start to peak of collision force of floating bodies.
\end{abstract}

\section{1. はじめに}

建物などは津波の氾濫流そのものだけでも大きな流体 力を受けて被害を生じるが，氾濫流が漂流物を伴えば，そ れらの被害は一層大きなものとなる.

にもかかわらず，氾濫した津波の先端部背後の準定常 的な流れによる持続波圧時の波力への動圧の寄与一つを 取り上げても，その実際はよく判っていない。動圧の寄 与，すなわち波圧の鉛直分布は建物（津波避難ビルなど） の津波に対する構造安全性などに深く係わり, その実際 を知ることは重要である。

また，町中を汇濫する津波は多かれ少なかれ雑多な漂 流物を伴い, その中で大きな漂流物（流木, 船やコンテ ナ等）が建物などに大被害を及ぼす。これまでの研究成 果により，漂流物の衝突速度が判れば，単体の流木（松 冨, 1999 ; 池野・田中, 2003） やコンテナ（水谷ら, 2005) の衝突力 $F_{m}$ は評価が可能となっている. 漂流物の衝突力 問題では, 衝突速度はもちろんのこと, 衝突確率や衝突 力立ち上がり時間 $\Delta t_{p}$ (図-1), 衝突力継続時間 $\Delta t$ (図-1), 衝突力の確率分布の検討も必要である. しかし, これら については個別に検討が行われてきており，互いを結び つけて総合的に論じたものはない.

そこで, 本研究は, 先ず既往の研究成果の考察に基づ いて，津波氾濫流による持続波圧時の動圧の寄与につい て検討を行う。次に, 漂流物の衝突速度や衝突確率, 衝 突力立ち上がり時間, 衝突力継続時間を互いに結びつけ て, 漂流物の衝突力確率分布の一評価方法を, 上記各項 目の検討課題を論じながら提示する.

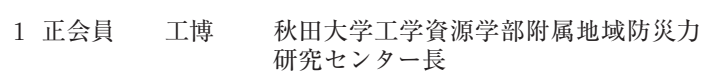

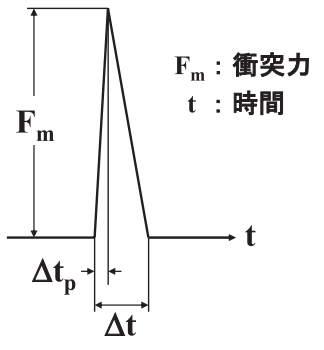

図-1 単体漂流物の衝突力波形（模式図）

\section{2. 動圧の寄与}

津波氾濫流による持続波圧時の動圧（流体運動に起因 した静水圧からのずれの全圧力）の寄与については, 類 似した現象を含めて, 現象毎に検討し判断する.

\section{（1）波浪の砕波}

津波汇濫流ではないが，類似した現象による流体力（波 力）の評価式として, Hiroi (1919）の砕波圧式がある. 波 浪が防波堤の天端を越波しないとき, その砕波圧式に基 づく単位幅あたりの水平波力 $F$ は式（1）で評価される.

$$
F=1.5 \rho g H(h+1.25 H)>\frac{1}{2} \rho g(h+1.25 H)^{2}-\frac{1}{2} \rho g h^{2} \cdots(1)
$$

ここで, $\rho$ は流体の密度, $g$ は重力加速度, $H$ と $h$ は防波堤 前面（沖側）における入射波高と静水深である.この波 力は, どのような $H$ の值に対しても, 静水圧分布とした ときのもの（式（1）の不等号の右辺）より大きく, 動圧 を含んでいることになる（Hiroiの砕波圧式は噴流の動圧 として誘導されており，論をまたないだろう).

一方，防波堤岸側の静水圧を無視した式（2）のときは,

$$
F=1.5 \rho g H(h+1.25 H)>\frac{1}{2} \rho g(h+1.25 H)^{2}
$$

$H / h>4 / 7=0.57$ のとき, 動圧が寄与することになる． 


\section{(2) 砕波後の波浪}

本間ら（1963）と富永・九津見（1971）の海域に設置 した鉛直壁構造物に対する砕波後の波による単位幅あた りの水平波力の評価式は各々次式である（松冨ら, 2004).

$$
\begin{aligned}
& F=\frac{1.73}{2} \rho g\left(h_{f}^{2}-h_{r}^{2}\right) \ldots \\
& F=\frac{2.91}{2} \rho g\left(h_{f}^{2}-h_{r}^{2}\right) \ldots
\end{aligned}
$$

ここで, $h_{f}$ は構造物前面 (沖側) の浸水深, $h_{r}$ は構造物背 面（岸側）の浸水深である. 本間らと富永・九津見の実 際の波力評価式は式（3）と（4）において $h_{r}=0$ としたも のである.したがって, 両式は各々静水圧の 0.73 倍と 1.91 倍の動圧を考慮していることになる（図-2).

\section{（3）非砕波津波のサージ}

林・松富（1977）はV字型湾の湾奥に位置する鉛直壁 の津波水門に対する波力実験で, 非砕波時の最大水平波 力は最大浸水深時の静水圧によるものの $1.0 \sim 1.5$ 倍にな ることを示している. したがって，静水圧の $0 \sim 0.5$ 倍以 上の動圧が働いていることになる.

\section{(4) 砕波段波}

松富（1991）は鉛直壁への砕波段波衝突時の波圧分布 の実験を行い，各高さでの最大波圧（同時刻のものとは 限らない）を鉛直方向に積分したときの単位幅あたりの 水平波力 $F_{z m}$ (過大評価となる) として, 次式を提示して いる.

$$
F_{z m}=4.0 \rho g \Delta H^{2}+2.8 \rho g \Delta H h_{0}>\frac{1}{2} \rho g\left(2 \Delta H+h_{0}\right)^{2}
$$

ここで， $\Delta H$ は入射段波波高， $h_{0}$ は段波前面の静水深であ る. この水平波力は, $\Delta H / h_{0}>0.34$ のとき, 静水圧分布と したときのもの（式（5）の不等号の右辺）より大きく, 動圧が寄与することとなる. $\Delta H / h_{0}<0.61 \sim 0.64$ のとは 波状段波であり（松冨，1989），式（5）は波状段波のと きも動圧が無視できない場合があることを示している.

\section{（5）河川の氾濫流}

福岡ら（1997）は河川氾濫流の模型実験で圧力は静水 圧分布することを報告している．ただし，フルード数が $0.55 \sim 0.57$ 程度の定常な常流実験での結果である. 河原ら （2009）も，非定常な常流と射流の実験で，河川氾濫流に よる圧力は静水圧分布することを報告している.

\section{（6）段波や正弦波の氾濫流}

飯塚・松冨（2000）は，平坦な陸上に氾濫する段波津 波の建物などへの流体力 $F_{D}$ は抗力が主体的で，氾濫流速 の自乗に比例するとして, 実験的に次式を提案している.

$$
F_{D} \cong 0.61 \rho g C_{D} h_{f}{ }^{2} B
$$

ここで, $C_{D}(=1.1 \sim 2.0)$ は抗力係数, $B$ は汇監方向への 建物などの投影幅である。この評価式は， $0.61 C_{D}>0.5$ で あるから, 静水圧の $0.3 \sim 1.4$ 倍の動圧を考慮しているこ とになる. 式（6）の誘導において, 汇濫流速として現地 データを包絡するという同じ考えに基づいた小さい方 $\left(u=0.6 \sqrt{g h_{f}}\right.$ (松冨ら, 2008)）を採用すれば, 次式を得る.

$$
F_{D} \cong 0.19 \rho g C_{D} h_{f}{ }^{2} B
$$

式（7）の場合, 流体力は静水圧よりも小さいことになる.

朝倉ら（2000）と池野・田中（2003）は護岸を越流し, 平坦な陸上を汇濫する津波の建物などへの波圧は静水圧

\begin{tabular}{|c|c|c|c|c|c|c|}
\hline & 対象の現象 & 現象発生法（定常·非定常） & 常流·射流 & 動压 & 動圧／静水圧 & 対象物 \\
\hline Hiroi（1919） & 波浪の砕波 & 波 (非定常) & - & 有 & 条件付き & 鉛直壁 \\
\hline 本間ら（1963） & \multirow{2}{*}{ 砕波後の波浪 } & \multirow{2}{*}{ 波（非定常） } & \multirow{2}{*}{-} & 有 & 0.73 & 鉛直壁 \\
\hline 富永·九津見（1971） & & & & 有 & 1.91 & 鉛直壁 \\
\hline 林・松冨（1977） & 非砕波津波のサージ & 波（非定常） & - & 有 & $0 \sim 0.5$ 以上 & 津波水門 \\
\hline 松富 (1991) & 砕波段波 & ゲート急開流れ (準定常) & $F_{r}=0.8 \sim 1.7$ & 有 & 条件付き & 鉛直壁 \\
\hline 福岡ら（1997） & 河川の氾濫流 & 定常流 & $F_{r}=0.55 \sim 0.57$ & 無 & - & 建物 \\
\hline 飯塚·松冨（2000） & 段波の氾濫流 & ゲート急開流れ (準定常) & 常流～射流 & 有 & $0.3 \sim 1.4$ & 建物 \\
\hline 朝倉ら（2000） & 正弦波の氾濫流 & 流量調節 & $F_{r}=2.0$ & 無 & 条件付き & 建物 \\
\hline 池野·田中（2003） & 段波の汇濫流 & ゲート急開流れ (非定常) & $F_{r}=2.4$ & 無 & - & 建物 \\
\hline 松冨ら（2004） & 段波の氾濫流 & ゲート急開流れ (準定常) & 常流～射流 & 有 & $0.73 \sim 1.91$ & 建物 \\
\hline 河原ら（2009） & 河川の氾濫流 & ゲート急開流れ (非定常) & 常流～射流 & $\begin{array}{ll}\text { 無 } \\
\end{array}$ & - & 建物 \\
\hline
\end{tabular}
分布する（ソリトン分裂する場合を除く）と考えている.

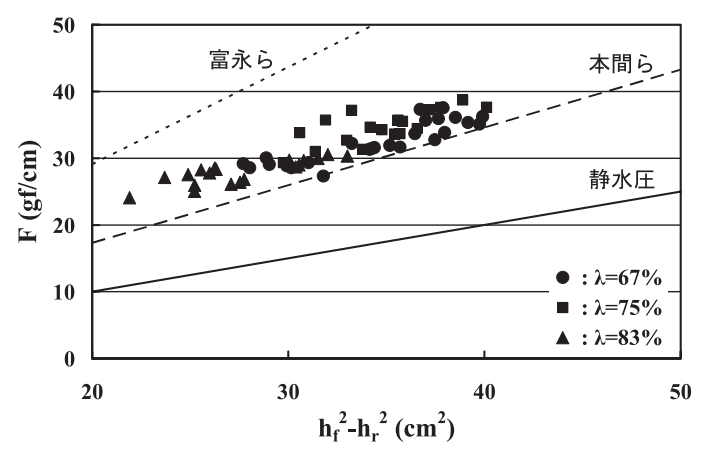

図-2 波力と構造物前・背面浸水深の2乗差の関係

表-1 動圧の寄与 
ともに建物などにとって危険な場合を想定しており，朝 倉らの波力評価式はフルード数 $F_{r}=2.0$, 池野 ·田中の波力 評価式は $F_{r}=\sqrt{6} \cong 2.4$ の汇濫流を対象としている.

松冨ら（2004）は一様勾配斜面上を伝播した後, 平坦 な陸上に汇濫する段波津波の建物への波圧実験を行って いる．ただし，建物は流れ横断方向において左右対称と 考え, 水路側壁に密着させた半分模型（岡本・松冨，2009） である．汇濫流先端部背後の準定常的な部分で，建物の 前面での波力が最大となるときの波力は本間らと富永・ 九津見の評価式によるものの間で（図-2）, 動圧の寄与が 無視できないと報告している. 図-2中の $\lambda(=100 \times(1$-建 物模型の幅／水路幅））は開度（\%）である.

\section{(7) 検討結果}

検討結果をまとめると表-1のようになる，既往の実験 は持続波圧時の最大波力を対象とし, 多くは動圧の寄与 が無視できないことを示している. 動圧の寄与が無視で きない理由の 1 つして, 静水圧状態となる前に最大波力 が生じていることが考えられる. 動圧の寄与度は実験に おける汇濫流の発生方法, フルード数と定常・非定常に 大きく左右される.

\section{3. 衝突力の確率分布}

\section{(1) 衝突速度}

衝突力 $F_{m}$ は衝突速度に強く依存する（松富，1999）。漂 流物の衝突速度として, 式（8）と（9）の漂流物を伴う 汇濫流の流速 $u_{2}$ を採用する（松冨ら, 2007). 町中の津波 汇濫流は漂流物を伴う場合が一般的で, 初期の漂流物群 の空隙率 $e$ が現実的な值であれば, これらの式は有用であ ることが確かめられている（松冨・古戸，2008）。

$$
u_{2}=\frac{\left[\left\{\left(\frac{\rho}{\rho_{0}}-\frac{\rho_{f}}{\rho_{0}}\right) e+\frac{\rho}{\rho_{0}}\left(\frac{h_{2}}{h_{0}}-1\right)\right\} \omega+\left\{1+\left(\frac{\rho_{f}}{\rho_{0}}-1\right) e\right\} u_{0}\right]}{\left[\left\{1+\left(\frac{\rho}{\rho_{0}}-1\right) e\right\}+\frac{\rho}{\rho_{0}}\left(\frac{h_{2}}{h_{0}}-1\right)\right]} \cdots(8
$$

$$
\begin{gathered}
\omega=u_{0}+\sqrt{\frac{g\left[\left\{\frac{\rho_{0}}{\rho}+\left(1-\frac{\rho_{0}}{\rho}\right) e\right\} h_{0}+h_{2}-h_{0}\right]}{\left\{1+\left(\frac{\rho_{f}}{\rho_{0}}-1\right) e\right\}\left\{\left\{1-\frac{\rho_{f}}{\rho}\right) e+\frac{h_{2}}{h_{0}}-1\right\}}} \\
\times \frac{\sqrt{\left[\frac{1}{2} \frac{\rho}{\rho_{0}}\left(\frac{h_{2}}{h_{0}}-1\right)^{2}+\left\{1+\left(\frac{\rho}{\rho_{0}}-1\right) e \frac{h_{2}}{h_{0}}\right.\right.}}{\left.-\frac{1}{2}\left\{2(1-e)+\left(\frac{\rho}{\rho_{0}}+\frac{\rho_{f}}{\rho_{0}}\right) e\right\}-\mu \frac{\rho_{a}}{\rho_{0}} \frac{L}{h_{0}} \frac{h_{2}}{h_{0}}\right]}
\end{gathered}
$$

ここで, $\rho_{0}$ は漂流物の密度, $\rho_{f}$ は氾濫流下流域の漂流物群 空隙部の密度 (空気の場合は零), $h_{2}$ は汇濫流上流域の水 深 (汇濫水深), $h_{0}$ は汇濫流上・下流域の漂流物層の厚さ, $\omega$ は氾濫伝播速度, $u_{0}$ は汇濫流下流域の流速 (一般に零), $\mu$ は合成摩擦係数, $\rho_{a}\left(=\rho_{0} \sim \rho\right)$ と $L$ は各々汇濫流先端部の
漂流物域層の密度と水平長さである。この汇濫流速 $u_{2}$ の 評価では, $\mu$ や $\rho_{a}, L$ の個々の評価よりも, 総合抵抗係数 $\left(\mu \rho_{a} L / \rho_{0} h_{0}\right)$ としての評価がより実際的で重要な課題であ る.

漂流物が汇濫流に影響を及ぼさない程度に少ないとき は，次式（岡本・松冨，2009）を用いて評価する.

$$
\begin{aligned}
& u_{2}=0.66 \sqrt{g h_{f}} \\
& u_{2}=1.2 \sqrt{g h_{r}} .
\end{aligned} .
$$

ここで, $h_{f}$ と $h_{r}$ は津波氾濫域の建物などに流れが作用する 面 (前面) とその背面での浸水深である. 式（10）と（11） の氾濫流速は建物などにとって危険側（最も大きな流体 力が作用）を考えたときのものである. 岡本・松冨 (2009) によれば, この評価式の利用に際し, 建物などの形状（角 柱, 円柱, 円錐）を考慮する必要はあまりない。

\section{(2) 衝突確率}

漂流物の衝突では, 単体の衝突ばかりでなく, 複数が 同時やほぼ同時に衝突するときも考えておく必要がある. 複数が同時やほぼ同時に衝突するときは，より大きな合 成衝突力 $F_{c}$ が働き (図-3), その衝突力ばかりでなく, 衝 突確率の検討も欠かせない.

流木であるが, 衝突確率の研究例として松冨・田名部 （2006）や戸来（2009）の実験的なものがある. それらの 実験結果によれば，流れ横断方向（ $y$ 方向）への流木の横 拡散位置に関する頻度の確率分布 $K_{y}(x, y)$ は次式の正規分 布で近似でき，

$$
K_{y}(x, y)=\frac{1}{\sqrt{2 \pi} \bar{\delta}_{y}} \exp \left[-\frac{(y-\bar{y})^{2}}{2 \bar{\delta}_{y}^{2}}\right]
$$

分散 $\bar{\delta}_{y}^{2}(x)$ は単調増加で, 次式で近似できる（図-4).

$$
\bar{\delta}_{y}^{2} / L_{w}^{2}=\frac{1}{n} \sum_{i=1}^{n}(y-\bar{y})^{2} / L_{w}^{2}=a\left(x / L_{w}\right)^{b}
$$

ここで, $L_{w}$ は流木長, $x$ は流れ方向に取った流木の流下距 離座標 (流木投入地点が原点), $y$ と氟は $x$ 地点での流木の 流れ横断方向位置座標とその平均位置座標, $n$ はデー夕数 である. $a$ と $b$ の值は今後の検討課題で, 漂流物の種類や フルード数などの水理量に依存しょう.

流木投入地点 $(0,0)$ から $(x, y)$ までの漂流時間を $t$,

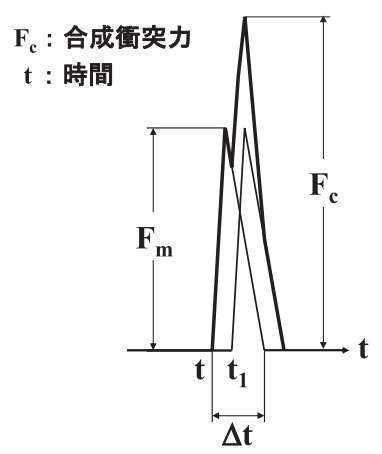

図-3 合成衝突力波形（模式図） 


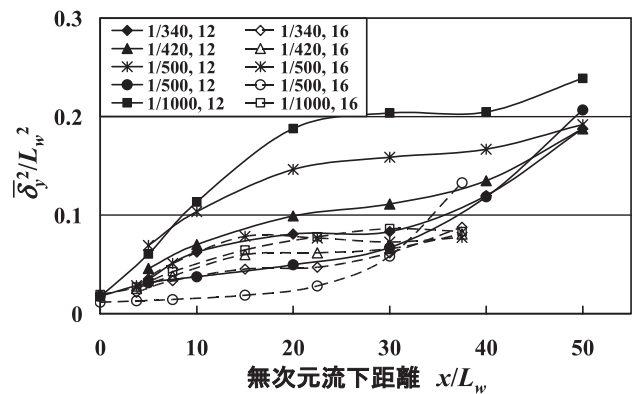

図-4 流下距離による横拡散の分散の変化例（戸来，2009） (凡例の分数と整数は底勾配と細長比, 流木径 $D_{w}$ は $1 \mathrm{~cm}$ )

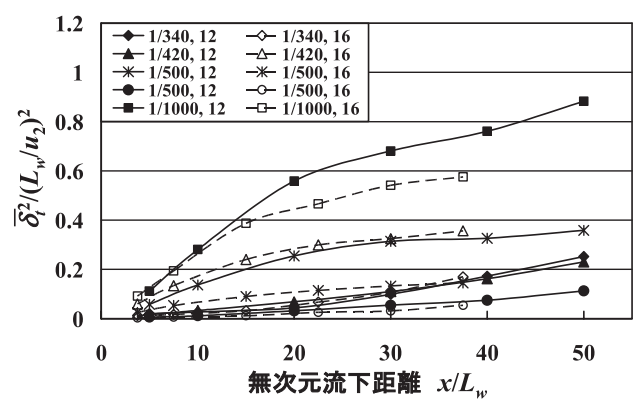

図-5 流下距離による縱分散の分散の水路横断方向平均の変 化例（戸来，2009）（凡例と流木径は図-4 と同じ）

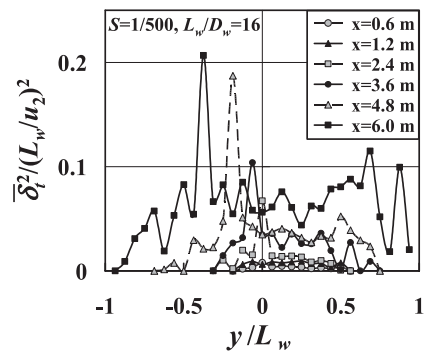

図-6 縦分散の分散の水路横断方向の変化例（戸来，2009）

その平均時間を $\bar{t}(x, y)$ とすれば（移流拡散 + 縦拡散 $=$ 縦分 散 $),$ この漂流時間の頻度の確率分布 $K_{t}(x, y, t)$ も次式の 正規分布で近似でき（松富・田名部，2006）,

$$
K_{t}(x, y, t)=\frac{1}{\sqrt{2 \pi} \bar{\delta}_{t}} \exp \left[-\frac{(t-\bar{t})^{2}}{2 \bar{\delta}_{t}^{2}}\right]
$$

分散 $\bar{\delta}_{t}^{2}(x, y)$ は次式で近似できる(図-5，6).

$$
\frac{u_{2}^{2}}{L_{w}^{2}} \bar{\delta}_{t}^{2}=\frac{1}{n_{t}} \sum_{i=1}^{n_{t}}(t-\bar{t})^{2} /\left(\frac{L_{w}}{u_{2}}\right)^{2}=c\left(\frac{x}{L_{w}}\right)^{k}+m\left|\frac{y}{L_{w}}\right|^{r} \cdots
$$

ここで, $n_{t}$ は $(x, y)$ を通過する流木の本数, $c$ と $k, m, r$ の值は今後の検討課題で, やはり漂流物の種類やフルー ド数などの水理量に依存しょう. $t-\bar{t} の$ 值域としては 0 $\Delta t$ 程度を考えておけば十分であろう。

よって, 流木 1 本が $(x, y, t)$ で衝突する確率 $p_{1}$ は,

$$
p_{1}(x, y, t)=K_{y}(x, y) K_{t}(x, y, t)
$$

流木 2 本が同時やほほ同時に衝突する確率 $p_{2}$ は,
1.

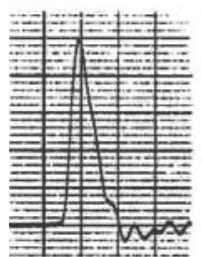

2.

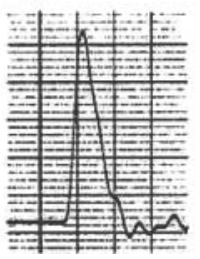

3.

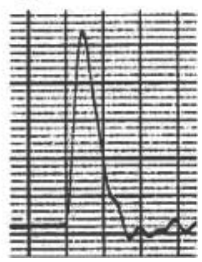

図-7 流木衝突力の時間波形例（ゲート急開流れの初期貯水 深 $h_{1}=0.4 \mathrm{~m}, h_{0}{ }^{\prime}=0.02 \mathrm{~m}, L_{w} / D_{w}=8, D_{w}=0.12 \mathrm{~m}, \lambda=87 \%$ )

$$
p_{2}(x, y, t) \cong p_{1}(x, y, t) p_{1}\left(x, y, t_{1}\right)
$$

ただし，式（13）と（15）の分散は十分に大きく, $\left|t-t_{1}\right|<\Delta t$ (図-3), 両流木は同じ諸元で, 完全に隣り合っ ていて，互いに影響を及ぼし合わないとしている．流木 が3本以上のときも同様に容易に議論できる.

\section{（3）衝突力継続時間と衝突力立ち上がり時間}

漂流物の衝突力継続時間 $\Delta t$ を検討した研究例として松 冨（1993）の実験的なものがある. 硗波段波に伴う流木 のときのもので，この結果を利用するには式（8）と（9) に示された漂流物を伴うときの $u_{2}, h_{2}, \omega$ と松冨の确波段 波実験でのそれらを一致させ, 漂流物を伴う氾濫流の場 合の段波下流側水深 $h_{0}$ を松富の砕波段波実験での下流側

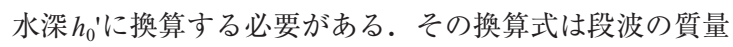
保存則から次式となる.

$$
\frac{h_{0}^{\prime}}{h_{2}}=1-\frac{u_{2}}{\omega}
$$

建物などの障害物がない開度入が100\%のときを考えれ ば，衝突力継続時間 $\Delta t$ として次式を得る（松冨，1993）.

$$
\Delta t=0.476\left(\frac{h_{2}}{h_{0}^{\prime}}-1\right)^{-0.054}\left(\frac{L_{w}}{D_{w}}\right)^{0.244}\left(\frac{u_{2}}{\sqrt{g D_{w}}}\right)^{0.415} \sqrt{\frac{D_{w}}{g}} \cdots
$$

ここで， $D_{w}$ は流木径である. 式（19）における相対段波 波高 $\left(h_{2} / h_{0}{ }^{\prime}-1\right)$ のべき指数が非常に小さいので, 衝突力 継続時間は次式で評価してもよい。

$$
\Delta t=0.476\left(\frac{L_{w}}{D_{w}}\right)^{0.244}\left(\frac{u_{2}}{\sqrt{g D_{w}}}\right)^{0.415} \sqrt{\frac{D_{w}}{g}}
$$

式 (20) から, 衝突力継続時間は流木の諸元と衝突速度で 決まることが判る. 実際は流木の単位体積重量, 降伏応 力, 見かけの質量係数, 被衝突物の剛性にも依存する.

衝突力立ち上がり時間 $\Delta t_{p}$ （図-1）も情報として必要で ある．衝突力の経時変化は三角形で近似できるので（松 冨, 1993), それは簡単に次式で評価する。

$$
\Delta t_{p}=\alpha \Delta t
$$

図-7に示した松富（1993）の流木衝突力の時間波形に関 する実験結果（横軸：時間, 縦軸：衝突力）によれば, $\alpha=0.2 \sim 0.25$ で, 衝突力の再現性がよいことも判る.

衝突力, 衝突力継続時間や衝突力立ち上がり時間は漂 流物や被衝突物の種類, 計測器機の性能などに依存する ので，式（19）のような便宜的なものではなく, 細心の 


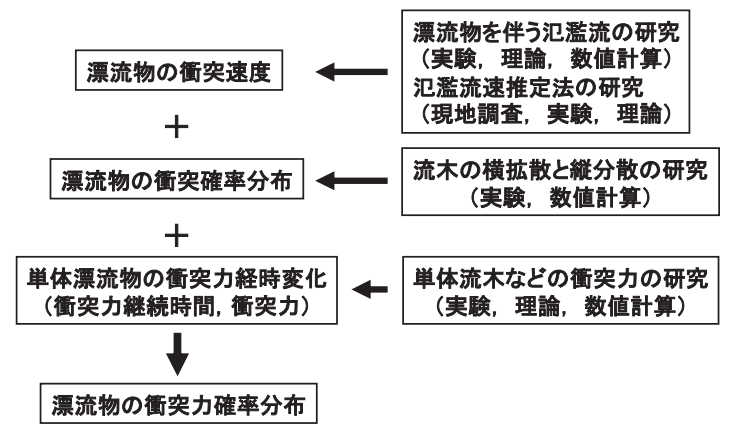

図-8 津波汇濫流に伴う漂流物の衝突力確率分布の評価手順 と検討課題例

注意と広範な条件の実験に基づいた検討が必要である.

\section{（4）衝突力の確率分布}

例えば，流木2本がほぼ同時に衝突するときの衝突力波 形は本研究の考え方では図-3の太実線のようになる.

単体漂流物の衝突力評価式として, 流木に関しては松 冨（1999）や池野・田中（2003）のもの，コンテナに関

しては水谷ら（2005）のものなどを採用すればよい.

これらの評価式に上述した漂流物の衝突確率 $p_{2}$ や衝突 時間差 $t_{1}-t$, 衝突力立ち上がり時間 $\Delta t_{p}$, 衝突力継続時間 $\Delta t$ を組み合わせれば, 本研究目的の衝突力の確率分布が 評価できることになる。

漂流物が $t=\tau$ に衝突したときの衝突力の時間波形 $F_{\tau}(t)$ は 次式となる.

$$
\begin{aligned}
F_{\tau}(t) & =\frac{F_{m}}{\Delta t_{p}}(t-\tau)\left(\tau \leq t \leq \tau+\Delta t_{p}\right) \\
& =\frac{F_{m}}{\Delta t-\Delta t_{p}}(\tau+\Delta t-t)\left(\tau+\Delta t_{p}<t \leq \tau+\Delta t\right)
\end{aligned}
$$

したがって，漂流物が $t=\tau$ と $t_{1}$ に衝突したときの最大合成 衝突力 $F_{c}$ は次式となり,

$$
F_{c}(x, y, t)=\left|F_{\tau}(t)+F_{t_{1}}(t)\right| \cdots
$$

その衝突確率は式（17）において $t$ を $\tau$ としたものとなる.

図-8に衝突力の確率分布の評価手順例とそのための検 討課題例を示す.

\section{4. おわりに}

本研究で得られた主な結論は次の通りである.

(1) 既往の実験は持続波圧時の最大波力を対象とし, 多く は動圧の寄与が無視できないことを示している．動圧 の寄与が無視できない 1 つの理由として, 静水圧状態と なる前に最大波力が生じることが考えられる．動圧の 寄与度は実験における汇濫流の発生方法, フルード数 と定常・非定常に大きく左右される.

(2) 津波氾濫流に伴う漂流物 (流木) の衝突力確率分布の 一評価方法を提示するとともに，検討課題を示した。

(3) 既往の実験結果によれば, 衝突力立ち上がり時間 $\Delta t_{p}$
と衝突力継続時間 $\Delta t$ の比 $\alpha$ は $0.2 \sim 0.25$ ある.

謝辞: 平成 20 年度の科研費基盤研究 (C) と北東北 3 大 学連携研究プロジェクトの補助を受けた。謝意を表する。

\section{参 考 文 献}

朝倉良介・岩瀬浩二 ・ 池谷 毅 - 高尾 誠 - 金戸俊道 - 藤井 直樹・大森政則（2000）：護岸を越流した津波による波力 に関する実験的研究, 海岸工学論文集, 第 47 巻, pp. 911915.

飯塚秀則・松冨英夫（2000）: 津波氾濫流の被害想定, 海岸工 学論文集, 第47巻, pp. 381-385.

池野正明 - 田中宽好（2003）: 陸上遡上津波と漂流物の衝突力 に関する実験的研究, 海岸工学論文集, 第 50 巻, pp. 721725 .

岡本憲助・松冨英夫（2009）：津波氾濫流速の簡易推定法に関 する基礎的研究, 海岸工学論文集, 第 56 巻. (印刷中)

河原能久 - 伊藤 康 - 内田龍彦 - 家藤憲司 (2009)：非定常流 中の建物に作用する流体力の直接測定, 水工学論文集, 第 53 巻, pp. 979-984.

富永正照・九津見生哲（1971）：海岸堤防に作用する砕波後の 波圧，第18回海岸工学講演会論文集，pp. 215-221.

林 泰造・松冨英夫（1977）：津波水門に加わる津波の波力に 関する実験的研究, 土木学会第 32 回年次講演会概要集, pp. 117-118.

福岡捷二・川島幹雄・横山 洋 - 水口雅教 (1997)：家屋群に 作用する氾濫流の流体力に関する実験的研究，水工学論 文集，第41巻, pp. 693-698.

戸来 啓 (2009)：流木の横拡散と移流拡散に関する実験的検 討, 秋田大学工学資源学部土木環境工学科卒業論文, 69 p.

本間 仁・堀川清司・長谷直樹（1963）：海岸堤防（護岸） に作用する波圧の分布について, 第 10 回海岸工学講演会 講演集, pp. 116-120.

松富英夫（1989）：移動跳水（波状段波非）発生条件の検討, 第33回水理講演会論文集, pp. 271-276.

松富英夫（1991）：砕波段波衝突時の圧力分布と全波力, 海岸 工学論文集, 第 38 卷, pp. 626-630.

松冨英夫（1993）：砕波段波に伴う流木の最大衝撃力に関する 実験的研究，土木学会論文集，No.467/II-23, pp. 19-28.

松冨英夫（1999）: 流木衝突力の実用的な評価式と変化特性, 土木学会論文集, No.621/II-47, pp. 111-127.

松富英夫 · 大向達也・今井健太郎 (2004) : 津波氾濫流の構造 物への流体力，水工学論文集，第48巻，pp. 559-564.

松富英夫 ・田名部 惊 (2006) : 流木の横拡散と移流拡散に関 する実験 一複数流木の衝突確率 - , 海岸工学論文集, 第 53 卷, pp. 186-190.

松冨英夫・藤井 碧・山口 健 (2007)：漂流物を伴う氾濫流 の基礎実験とモデル化，海岸工学論文集，第 54 巻，pp. 226-230.

松冨英夫・岡本憲助・佐藤和典（2008）：浸水痕跡に基づく簡 易氾濫流速推定法の基礎的検討，水工学論文集，第 52 巻, pp. 673-678.

松冨英夫・古戸貴大（2008）：漂流物を伴う氾濫流の水理量評 価法と基本特性, 海岸工学論文集, 第 55 卷, pp. 356-360.

水谷法実 ·高木祐介・白石和睦 - 宮島正悟 - 富田孝史 （2005）：エプロン上のコンテナに作用する津波力と漂流 衝突力に関する研究, 海岸工学論文集, 第 52 巻, pp. 741745 .

Hiroi, I. (1919): On a method of estimating the force of waves, 東京 帝大工科紀要, Vol.10, No.1, 19 p. 